Bull.Fac. Agric.,Cairo Univ.,63:275-285 (2012).

\title{
INFLUENCE OF COMBINED OSMOTIC DEHYDRATION AND AIR DRYING ON THE QUALITY OF GUAVA SLICES
}

(Received: 8. 4. 2012)

\author{
By \\ M.T.M. Assous, K.H.M. El-Waseif and S. M. Zaki \\ Food Technology Research Institute, Agricultural Research Center, Giza, Egypt.
}

\begin{abstract}
This study was carried out to investigate the effect of osmotic dehydration on moisture content of guava slices during osmosis, the weight losses, solid gain and moisture losses parameters. Then the effect of the physical, chemical, microbiological characteristics and sensory attributes of the dried and osmo air dried guava slices were evaluated. The results showed that moisture content of guava slices was highly decreased in the first two hours during immersion in different osmotic solution regardless with and without the addition of calcium chloride. The results indicated that osmosis increased weight losses, solids gain and water losses from $29.7-43.48 \%$ of the initial weight, $16.19-18.66 \%$ of the initial solid and $46.34-62.46 \%$ of the initial water in osmotically dehydrated guava slices, respectively. The results indicated that total sugar, ascorbic acid and phenolic contents of osmo airdried guava slices were higher than that of air dried guava slices. The results showed that drying ratio of the osmosed samples ranged from 2.63:1 to 2. 86:1 regardless with and without addition of calcium chloride, while drying ratio of air dried guava slices without osmosis (the control) was 6.52:1. The results illustrated that overall acceptability scores of osmo air-dried prepared with sucrose solution or sucrose: fructose solution and sucrose: glucose at a ratio 1: 1(wt:wt) with adding calcium chloride were highly significant followed the same treatments without adding calcium chloride.
\end{abstract}

Key words: air drying, guava, osmotic dehydration.

\section{INTRODUCTION}

Guava (Psidium guajava L., family Myrtaceae) is a popular fruit tree of the tropics and subtropics countries and is important in international trade and domestic economy of several countries in warmer climates. Also, guava fruit is rich in vitamin $\mathrm{C}$ and also a good source of pectin and dietary fiber(Jaiswal and Jaiswal, 2005 and Rai et al.,2008 ).Guava, as in many other fruits and vegetables, is also rich in antioxidant such as phenolic compounds, ascorbic acid that helps to reduce the incidence of degenerative diseases (Yan et al.2006). Psidium guajava, is an important food crop and medicinal plant in tropical and subtropical countries and widely used like food and in folk medicine around the world. The main traditional use known is as an anti-diarrhoeal. Other reported uses include gastroenteritis, dysentery, stomach, antibacterial colic pathogenic germs of the intestine (Gutierrez et al.,2008).

In spite of the fact that there are a variety of guava processed products, such as, marmalades, jellies, juices, and soft drinks, this fruit is usually consumed in the fresh stage. However, the exportation of fresh guavas from producing countries has been restricted because this fruit is highly perishable and susceptible to tropical fruit fly attack (Osorio et al.,2011).

Drying is essential to decrease water content to a level at which microbial spoilage and deterioration reactions are minimized. However, fruit and vegetable undergo physical, structural, chemical and nutritional changes during drying that can affect quality attributes like texture, color, flavor, and nutritional value (Di Scala and Crapiste, 2008). Food, such as fruits, has its weight reduced by approximately $50 \%$ of the original weight due to osmotic dehydration.This is a method used for attaining better quality fruits and it is used as a preliminary drying period, followed by baking or freezing(Park et al.,2002).

Osmotic dehydration can be used as a pretreatment for partial dehydration of fruits and vegetables. This technique also allows the incorporation of certain solutes, Osmotic dehydration (OD) of fruits has become relevant as a technique to decrease water activity, thus increasing the products stability .The kinetics of 
OD processes are usually evaluated in terms of water loss, weight loss and solids gain) Panades et al.2006).

Solute choice and concentration depend on several factors, namely the effect on organoleptic quality properties, solute solubility, cell membrane permeability, its stabilizing effect and cost (Qi et al.1998).

The objective of this study was to investigate the effect of osmotic dehydration with different sugar solution with and without the addition of calcium chloride and air drying on quality characteristics of guava slices.

\subsection{Materials}

\section{MATERIALS AND METHODS}

Guava fruit (Psidium guajava L.) at firm ripe stage was obtained from $6^{\text {th }}$ October market, Giza, Egypt in September, 2011. Fructose syrup 55 and glucoses syrup were obtained from the National Company for maize products, $10^{\text {th }}$ of Ramadan City, Cairo, Egypt. Sucrose was obtained from Sugar and Integrated Industries Co., Egypt. Citric acid, calcium chloride and potassium sorbate were obtained from El-Nasr Pharmaceutical Co., Egypt.

\subsection{Processing methods}

\subsubsection{Preparation of guava slices}

Guava fruits were washed, cut into slices (0.8 $1 \mathrm{~cm})$ and were exposed to steam water for $2 \mathrm{~min}$. at atmospheric pressure then coolded under tap water. The percentage of flesh, seeds and slices was calculated.

\subsubsection{Preparation of osmotic solution}

Sucrose, fructose and glucose solution concentrations at $60 \%$ were prepared; citric acid and potassium sorbate 0.5 and $0.2 \%$ respectively were added to each solution.

The prepared different osmotic solutions were divided into 6 groups as follows:- Sucrose solution (Sug.) ,sucrose: glucose (Sug:Glu.) at ratio 2:1(wt: wt ), sucrose: fructose (Sug:Fru.) at ratio 2:1(wt: wt ), Glucose(Glu.), fructose (Fru.) and glucose: fructose (Glu.:Fru.) at ratio 1:1(wt: wt ), respectively .

\subsubsection{Osmotic dehydration}

Guava slices were immersed in different osmotic solution at room temperature $\left(25 \pm 3^{\circ} \mathrm{C}\right)$ with and without the addition of $0.5 \%$ calcium chloride, using a mass ratio of fruit to the osmotic solution of 3:1 (wt :wt), respectively . Weight of guava slices was recorded at 2 hours intervals till it reached almost a constant level. Weight loss (WL), water loss(WR) and solids gain(SG) were calculated for the osmosed guava slices resulted from each treatment according to Correa et al.
(2010) as follows :-

$$
\begin{array}{lc}
\text { WL }(\%)=X_{0}^{s} M_{0}^{s}-X_{f}^{y} M_{f}^{s} / M_{0}^{s} & \text { x100 } \\
\text { SG }(\%)=X_{f}^{s t} M_{f}^{s}-X_{0}^{s t} M_{0}^{s} / M_{0}^{s} & \mathrm{x} 100 \\
\text { WR }(\%)=M_{0}^{s}-M_{f}^{s} / M_{0}^{s} & \mathrm{x} 100
\end{array}
$$

Where $M_{0}^{\circ}=$ initial sample weight $(\mathrm{kg}), M_{f=}^{\circ}$ final sample weight $(\mathrm{kg}), X_{o}^{w}=$ Initial moisture content $(\%), X_{f}^{w}=$ final moisture content $(\%), X_{0}^{s t}=$ Initial solids content $(\%), X_{f}^{s t}=$ final solids content $(\%)$.

\subsubsection{Drying}

Fresh blanched guava slices after immersing in $0.5 \%$ citric acid solution for $10 \mathrm{~min}$. and osmosed guava slices were dried in a convection oven at $60 \pm 3^{\circ} \mathrm{C}$ till moisture percentage reached $\sim 18 \%$. Samples were packed in polyethylene bags till analysis.

\subsection{Analytical methods}

Moisture, total soluble solids (TSS), $\mathrm{pH}$ value ,total titratable acidity, reducing, non reducing and total sugars ,crude fiber, ash and ascorbic acid contents were determined according to the method of AOAC (2005). Total phenolic content was determined by the Folin Ciocalteu method, which was described in Swain and Hillis (1959) and Thaipong et al.(2006). Antioxidant activity of samples extracts was studied through the evaluation of the free radical-scavenging effect on the 1, 1-diphenyl-2-picrylhydrazyl (DPPH) radical. The results were expressed as percentage of inhibition of the DPPH radical. Percentage of inhibition of the DPPH radical was calculated according to Alothman et al.(2009) using the following equation:-

$\%$ inhibition of DPPH $=\frac{\text { Abs control_Abs sample }}{\text { Abs control }} \times 100$

Where: Abs.control is the absorbance of DPPH solution without extracts, Abs.sample is the absorbance of DPPH with solution extracts.

Color of the fresh as well as the osmo air-dried and dried samples were measured according to Mercado-Silva et al.(1998) method using Hunter Lab model D-25 color and color difference meter . The $\mathrm{L}, \mathrm{a}$ and $\mathrm{b}$ values were recorded. White plate reflect values were used as a reference. Firmness was measured using Qc-Tech Universal Testing Machine (model B-type, Cometech Ltd,Taiwan) with a flat knife probe $(2.5 \mathrm{~mm}$ thickness $)$ at a crosshed speed of $100 \mathrm{~mm} \mathrm{~min} .^{-1}$ The results were reported as Newton $(\mathrm{N})$ according to the method described by Singh and Pal (2008). Drying ratio 
was calculated for samples after air drying according to Van-Arsdel and Copley (1964) as follows:-

$$
\begin{aligned}
& \text { Weight of fresh sample (before air drying) } \\
& \text { Drying ratio }=\text { Weight of dried sample (after air drying) }
\end{aligned}
$$

Sensory evaluation of osmo air -dried and dried samples were subjected according to Ranganna (1977). Overall acceptability score: taste +color +texture +flavor for sample divided by 4 . The results of sensory evaluation were statistically analyzed by ANOVA procedure of the SPSS statistical package (SPSS, 1990).Total bacterial counts as well as yeast and mould counts were determined according to the method described by APHA (1992).

\section{RESULTS AND DISCUSSION 3.1.Physicochemical properties of fresh guava fruit}

The data in Table (1) indicate that the T.S.S, $\mathrm{pH}$ value and the firmness $(\mathrm{N})$ of flesh guava fruit were $9.1 \%, 4.64$ and 80.55 , respectively. Also, the results in the same table reveal that total sugars, reducing and non-reducing sugars were $61.75,18.99$ and $42.76 \%$ (on dry weight basis), respectively. These findings are in accordance with those obtained by El Bulk et al. (1997), Khalil (1997) and Omar et al. (2007). The results in Table (1) illustrate that the total titratable acidity, ash, fiber of flesh guava fruits were 1.46, 2.18 and 17.47 (on dry weight basis), respectively. Also, the results in the same table indicate that the total phenols of the flesh of guava fruits were $275.89 \mathrm{mg} / 100 \mathrm{~g}$ on dry weight basis. These results are in good agreement with those reported by Bashir and Abu-Goukh (2003) who indicated that firmness and total phenols of guava fruits decreased gradually during ripening. They found that firmness $0.3 \mathrm{~kg} / \mathrm{cm}^{2}$ and the total phenols were $50 \mathrm{mg} / 100 \mathrm{~g}$ fresh white guava fruit at full ripe stage. Soares et al. (2007) showed that the chemical composition changed according to the cultivar and environmental conditions such as the climate and soil. Also, the results in Table (1) indicate that ascorbic acid and antioxidant activity of guava flesh were $733.28 \mathrm{mg} / 100 \mathrm{~g}$ (dry weight) and 77.26 as (\%) DPPH inhibition, respectively.It could be seen that guava flesh is good source of antioxidant capacity. This result is in agreement with those reported by Alothman, et al. (2009).
Table (1): Physical and chemical properties of

\begin{tabular}{|c|c|}
\hline Properties & Value \\
\hline Flesh & 89.54 \\
\hline Seeds & 10.46 \\
\hline Slices & 62.50 \\
\hline T.S.S & 9.1 \\
\hline $\mathrm{pH}$ value & 4.64 \\
\hline Firmness $(\mathrm{N})$ & 80.55 \\
\hline Color (Hunter lab) & \\
\hline L(lightness) & 57.40 \\
\hline $\mathrm{a}($ Redness) & 2.70 \\
\hline $\mathrm{b}($ Yellowness) & 23.63 \\
\hline $\begin{array}{l}\text { Total titratable acidity* } \\
\text { (as citric acid) }(\%)\end{array}$ & 1.46 \\
\hline Total sugars $* \quad(\%)$ & 61.75 \\
\hline Reducing sugars* & 18.99 \\
\hline Non-reducing sugars* $(\%)$ & 42.76 \\
\hline Crude fiber* & 17.47 \\
\hline Ash * $\quad(\%)$ & 2.18 \\
\hline Ascorbic acid* (mg/100 g) & 733.28 \\
\hline $\begin{array}{l}\text { Total phenolic compounds* } \\
(\mathrm{mg} / 100 \mathrm{~g})\end{array}$ & 275.89 \\
\hline Antioxidant activity $(\%)$ & 77.26 \\
\hline Moisture $\quad(\%)$ & 87.14 \\
\hline
\end{tabular}
fresh guava fruits.

*On dry weight basis

3.2. Effect of osmotic dehydration on moisture content of guava slices with and without calcium chloride

The results in Figs. (1\&2) show that moisture content of guava slices was highly decreased in the first two hours during immersion in different osmotic solution regardless with and without addition of calcium chloride. Tedjo et al. (2002) showed that mass transfer has been reported to occur mainly during the first hours after which the mass transfer rates become progressively lower until water loss diminishes whereas solute gain continued to increase steadily. Also, the results in the same Figures indicate that moisture content was highly decreased in immersion osmotic with the addition of calcium chloride than that without calcium chloride. Chardonnet et al. (2001) found that the addition of calcium chloride increased the osmotic potential of sucrose solution, resulting in greater water loss from apple slices. Moisture content became almost stable after 12 hours of osmotic process.

The results in Figs. (1\&2) illustrate that osmotic solution of reducing sugars caused higher reduction in moisture content of guava slices than other osmotic solutions. These results are in agreement with Bolin et al. (1983) and El- 


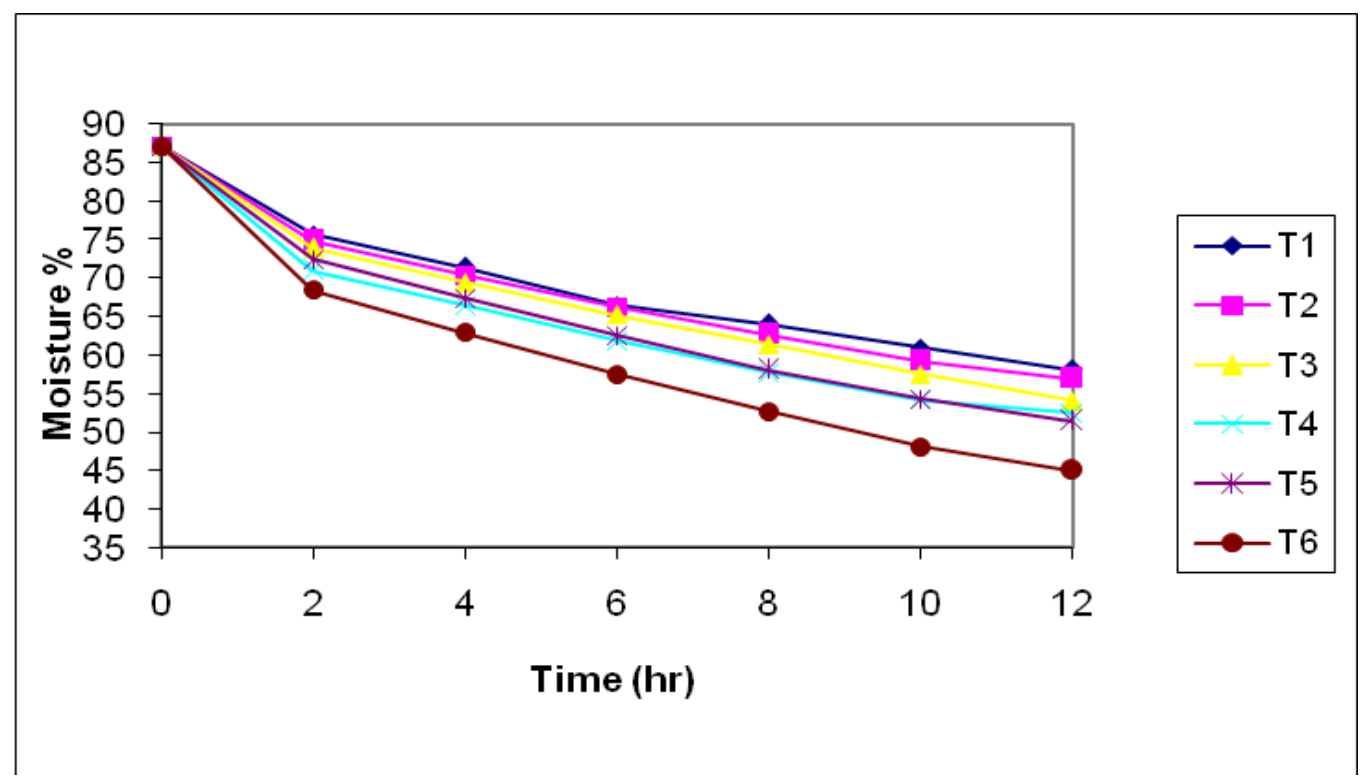

Fig.(1):Moisture content during osmotic dehydration of guava slices without the addition of calcium chloride

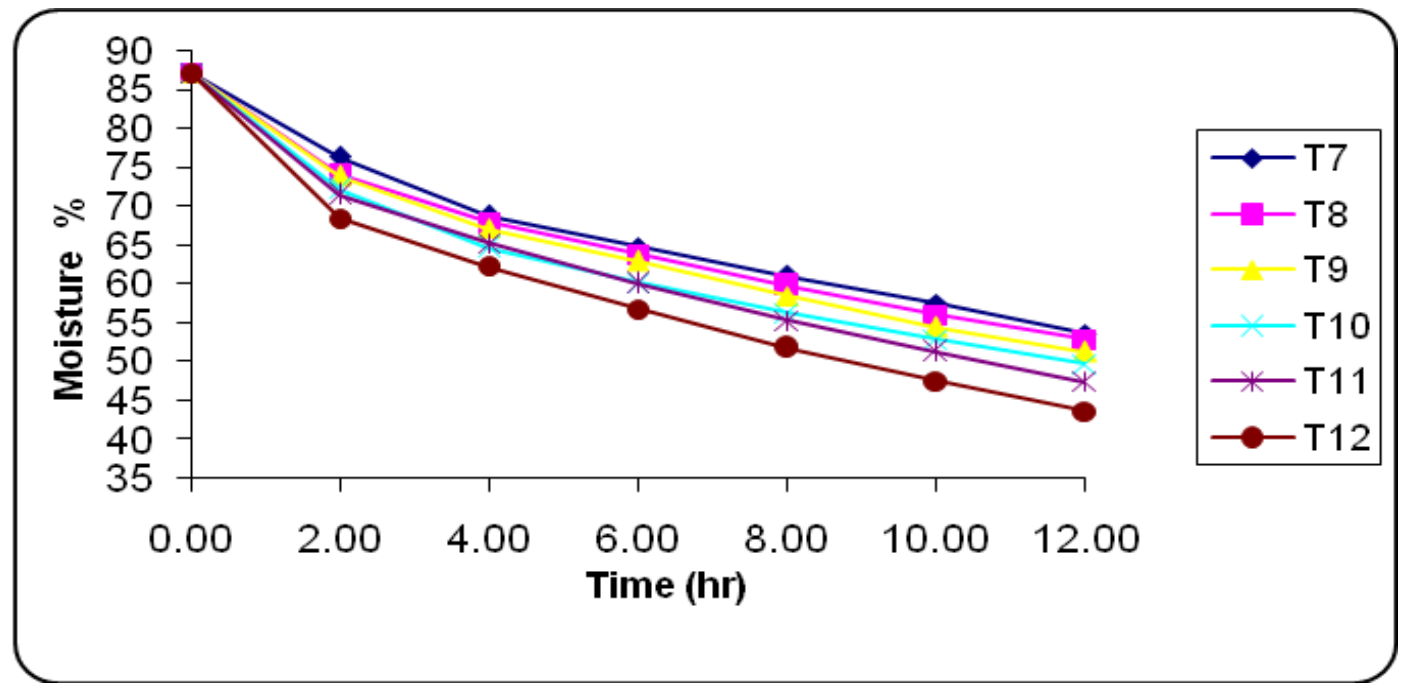

Fig.(2):Moisture content during osmotic dehydration of guava slices with the addition of calcium chloride.

Gharably et al. (2009). Ponting et al. (1966) found that invert sugar syrup was more effective than sucrose at the same concentration. Monsalve-Gonzalez et al. (1993) found that water lost from apple tissue was similar in glucose $\left(42^{\circ}\right.$ Brix $)$ or sucrose $\left(52^{\circ}\right.$ Brix $)$ solutions. Since solute uptake is by diffusion, they expected that sugar gain would be greater with decreasing solute molecular weight. They found that glucose uptake was significantly higher than sucrose for apple slices and cylinders.

\subsection{Effect of osmotic dehydration on weight loss, solid gain and water loss of guava slices with and without addition of calcium chloride}

The results in Table (2) show that using sugar solutions (glucose and fructose) caused a higher increase in weight loss, solid gain and water loss than that other sugar solution used. Weight loss\%(WL) after osmotic dehydration of guava slices was ranged from 29.7 to $43.48 \%$. The results in Table (2) show that solids gain of all treatments ranged from 16.19 to $18.66 \%$ 
Table (2): Weight loss, solid gain and water loss of guava slices with and without the addition of calcium chloride after osmotic dehydration.

\begin{tabular}{|c|c|c|c|}
\hline \multirow{2}{*}{$\begin{array}{c}\text { Treatments } \\
\text { (Osmotic solutions) } \\
\end{array}$} & Weight loss (\%) & Solid gain (\%) & Water loss (\%) \\
\hline & \multicolumn{3}{|c|}{ Without addition of calcium chloride } \\
\hline Suc. $\left(T_{1}\right)$ & 29.70 & 16.19 & 46.34 \\
\hline 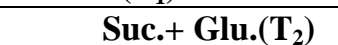 & $\mathbf{3 0 . 2 3}$ & 16.52 & 47.33 \\
\hline Suc.+ Fru.(T $\left.\mathbf{T}_{3}\right)$ & 33.07 & 17.38 & 50.96 \\
\hline Glu. $\left(\mathbf{T}_{4}\right)$ & 34.70 & 17.77 & 52.90 \\
\hline Fru. $\left(\mathbf{T}_{5}\right)$ & 35.85 & 17.89 & 54.15 \\
\hline \multirow[t]{2}{*}{ Glu+. Fru. $\left(T_{6}\right)$} & 42.17 & 18.57 & 61.14 \\
\hline & \multicolumn{3}{|c|}{ With addition of calcium chloride } \\
\hline Suc. $\left(\mathbf{T}_{7}\right)$ & 33.57 & 17.65 & 51.43 \\
\hline Suc.+ Glu. $\left(\mathbf{T}_{8}\right)$ & 34.26 & 17.91 & 52.37 \\
\hline Suc.+ Fru.( $\left.\mathbf{T}_{9}\right)$ & 35.90 & 18.19 & 54.29 \\
\hline Glu. $\left(\mathbf{T}_{10}\right)$ & 37.43 & 18.40 & 56.03 \\
\hline Fru. $\left(\mathbf{T}_{11}\right)$ & 39.71 & 18.63 & 58.54 \\
\hline Glu+. Fru. $\left(T_{12}\right)$ & 43.48 & 18.66 & 62.46 \\
\hline
\end{tabular}

regardless with or without addition of calcium chloride. These differences may be attributed to the molecular weight of the solutes, it appears that solutes in grape (glucose and fructose) must penetrate apple tissue more easily than sucrose (Mujica-Paz et al., (2003).Also, the results in the same table indicate that water loss \% of guava slices ranged from 46.34 to 62.46 for all treatments. The increase of the WL of guava slices with osmotic solutions (glucose or fructose) can be explained by the solute mechanism that is faster in penetration rate (Bolin et al.1983).

\subsection{Effect of drying on color parameter of}

\section{fresh and osmosed guava slices}

The results in Table (3) show the color measurements by Hunter Lab as L, a and b parameters after drying and osmo-air drying of guava slices. The results in Table (3) show that $\mathrm{L}$ and $b$. values of different pretreated samples were higher than that of guava dried slices (the control). Also, Tables (1 and 3) show that L (Lightness) values of dried guava slices treated with sucrose solutions with and without calcium chloride slightly decreased than fresh guava fruits. On the other hand, a. value (Redness) of dried guava slices (control) was higher than that pretreated sample fruits. It could be long time of drying for guava dried. Prothon et al.(2001) reported that dried apple cubs which treated with osmotic dehydration before drying were less brown than that without osmoisis. The same trend with the results of Taiwo et al. (2001) who found that browning effect was significantly lower in apple slices pretreated in concentrated solution of sucrose than in untreated samples. Also, the results in Table (3) illustrate that the individual using of glucose or fructose for osmotic solution increased darkening (a value) of guava osmo-air dried than that of the used sucrose solution.

Table (3): Color evaluation after drying of osmosed guava slices.

\begin{tabular}{|c|c|c|c|}
\hline \multirow[t]{2}{*}{ Treatments } & L(Lightness) & a(Redness) & b( Yellowness) \\
\hline & \multicolumn{3}{|c|}{ Without addition of calcium chloride } \\
\hline Suc. $\left(\mathbf{T}_{1}\right)$ & 54.18 & 4.65 & $\mathbf{1 7 . 8 1}$ \\
\hline Suc.+ Glu.( $\left.\mathbf{T}_{2}\right)$ & 51.14 & 5.33 & 17.00 \\
\hline Suc.+ Fru.( $\left.\mathbf{T}_{3}\right)$ & $\mathbf{5 2 . 3 6}$ & 4.91 & 17.37 \\
\hline Glu. $\left(\mathbf{T}_{4}\right)$ & 45.22 & 6.13 & 14.87 \\
\hline Fru. $\left(T_{5}\right)$ & 50.01 & 5.00 & 17.19 \\
\hline \multirow[t]{2}{*}{ Glu+. Fru. $\left(T_{6}\right)$} & 48.11 & 5.69 & 16.69 \\
\hline & \multicolumn{3}{|c|}{ With addition of calcium chloride } \\
\hline Suc. $\left(\mathbf{T}_{7}\right)$ & 56.19 & 4.50 & 18.14 \\
\hline Suc.+ Glu. $\left(\mathbf{T}_{8}\right)$ & 51.71 & 5.11 & 17.49 \\
\hline Suc.+ Fru.(T, $\left.\mathbf{T}_{9}\right)$ & 53.66 & 4.79 & $\mathbf{1 7 . 8 4}$ \\
\hline Glu. $\left(\mathbf{T}_{10}\right)$ & 47.12 & 6.02 & 16.81 \\
\hline Fru. $\left(\mathbf{T}_{11}\right)$ & 52.47 & 4.82 & 17.31 \\
\hline Glu+. Fru. $\left(T_{12}\right)$ & 49.44 & 5.33 & $\mathbf{1 7 . 5 9}$ \\
\hline Control & 33.92 & 7.66 & 12.06 \\
\hline
\end{tabular}


Carabasa-Giribet and Ibarz-Ribas( 2000) found that the activation energies for colorless browning intermediate formation increased with increasing glucose concentration.

\subsection{Effect of drying on physical-chemical} properties of fresh and osmosed guava slices

The results in Table (4) indicate that moisture content of dried and osmo-air dried guava slices ranged from 16.51 to $18.51 \%$. These results are in agreement with Egyptian standard (2007) for dried fruits. Results in Table (4) illustrate that firmness of guava air dried (control) were higher than that osmo-air dried. These results are in agreement with those reported by Prothon et al.(2001).Also, the same results showed that using glucose $\left(\mathrm{T}_{1}\right)$ or fructose solution $\left(\mathrm{T}_{5}\right)$ of osmotic process before drying where higher decreased firmness than that using sucrose solution $\left(\mathrm{T}_{1}\right)$. This could be due to that glucose and fructose are hygroscopic to water. The results in Table (4) show that reducing, nonreducing and total sugar contents for dried guava slices were $21.72,39.38$ and $61.10 \%$ (on dry weight basis), respectively. Also, the results in the same Table (4) show that reducing, nonreducing and total sugar contents of osmo-air dried guava slices without and with calcium

Table (4): Effect of drying on physical-chemical properties of osmo-air dried guava slices.

\begin{tabular}{|c|c|c|c|c|c|c|c|}
\hline \multicolumn{8}{|c|}{ Without the addition of calcium chloride } \\
\hline Characteristics & Control & $\mathbf{T}_{1}$ & $\mathbf{T}_{2}$ & $\mathbf{T}_{3}$ & $\mathbf{T}_{4}$ & $\mathbf{T}_{5}$ & $T_{6}$ \\
\hline pH value & 4.5 & 4.21 & 4.25 & 4.27 & 3.97 & 4.17 & 4.08 \\
\hline Firmness (N) & 185.10 & 128.85 & 125.93 & 127.18 & 105.78 & 116.18 & 108.00 \\
\hline Total titratable acidity* $(\%)$ & 0.930 & 0.613 & 0.625 & 0.627 & 0.618 & 0.619 & 0.615 \\
\hline Total sugars $*(\%)$ & 61.10 & 82.96 & 84.21 & 83.84 & 84.51 & 84.20 & 84.22 \\
\hline Reducing sugars* $(\%)$ & 21.72 & 12.72 & 46.96 & 46.86 & 68.18 & 68.14 & 68.48 \\
\hline Non-reducing sugars* $(\%)$ & 39.38 & 70.24 & 37.25 & 36.98 & 16.33 & 16.10 & 15.74 \\
\hline Crude fiber* $(\%)$ & 16.80 & 6.64 & 6.41 & 6.45 & 6.95 & 6.66 & 6.45 \\
\hline $\operatorname{Ash} *(\%)$ & 1.94 & 0.74 & 0.77 & 0.78 & 0.79 & 0.76 & 0.78 \\
\hline Ascorbic acid* (mg/100g) & 368.30 & 194.59 & 193.93 & 192.58 & 204.19 & 206.17 & 207.62 \\
\hline Total phenolic* (mg/100g) & 191.52 & 95.46 & 93.81 & 94.17 & 94.91 & 91.16 & 86.85 \\
\hline Antioxidant activity(\%) & 40.17 & 55.62 & 54.08 & 53.31 & 50.22 & 55.79 & 52.84 \\
\hline Moisture (\%) & 16.51 & 17.11 & 17.91 & 17.75 & 18.51 & 18.32 & 18.17 \\
\hline Drying ratio & $6.52: 1$ & 2.86:1 & 2.82:1 & $2.76: 1$ & $2.72: 1$ & 2.68:1 & $2.63: 1$ \\
\hline \multicolumn{8}{|c|}{ With the addition of calcium chloride } \\
\hline & $\mathbf{T}_{7}$ & $\mathbf{T}_{8}$ & $\mathbf{T}_{9}$ & $T_{10}$ & $T_{11}$ & & $T_{12}$ \\
\hline pH value & 4.31 & 4.30 & 4.29 & 4.28 & 4.45 & & 4.17 \\
\hline Firmness (N) & 142.03 & 136.95 & 139.68 & 113.11 & 125.77 & & 119.12 \\
\hline Total titratable acidity* $(\%)$ & 0.602 & 0.630 & 0.633 & 0.637 & 0.645 & & 0.650 \\
\hline Total sugars $*(\%)$ & 83.69 & 82.68 & 82.88 & 82.33 & 83.62 & & 83.79 \\
\hline Reducing sugars * $(\%)$ & 11.74 & 44.74 & 44.89 & 64.35 & 66.47 & & 65.94 \\
\hline Non-reducing sugars* $(\%)$ & 71.95 & 37.94 & 37.99 & 17.98 & 17.15 & & 17.85 \\
\hline Crude fiber* $(\%)$ & 6.72 & 7.00 & 7.01 & 7.43 & 7.12 & & 6.49 \\
\hline $\operatorname{Ash} *(\%)$ & 0.95 & 1.07 & 1.10 & 1.11 & 1.05 & & 1.00 \\
\hline Ascorbic acid* (mg/100g) & 197.34 & 194.45 & 196.48 & 207.53 & 208.09 & & 210.28 \\
\hline Total phenolic* (mg/100 g) & 96.43 & 93.51 & 97.28 & 95.28 & 91.02 & & 90.96 \\
\hline Antioxidant activity(\%) & 57.95 & 55.63 & 54.85 & 51.76 & 54.08 & & 53.31 \\
\hline Moisture (\%) & 17.15 & 17.00 & 17.45 & 17.75 & 18.02 & & 18.11 \\
\hline Drying ratio & $2.75: 1$ & 2.73:1 & $2.79: 1$ & $2.80: 1$ & $2.66: 1$ & & $2.69: 1$ \\
\hline
\end{tabular}

* On dry weight basis 
chloride were in the ranges of $11.74-68.48 \%$, $15.74-71.95 \%$ and $82.33-84.51 \%$ (on dry weight basis), respectively.

These results indicate that osmosis before air drying yielded products with higher total sugar content and the major increment was in the reducing sugar content especially when immersion in glucose or fructose solution. This result is in harmony with those reported by Assous (2004) and Zaki (2007). The results in Table (4) show that ash content in air dried guava slices was $1.94 \%$ (on dry weight basis) while it ranged from $0.74 \%$ to $1.11 \%$ (on dry weight basis) in the osmo-air dried guava slices of treatments without and with addition of calcium chloride. Also, in the same table, the results show that ash content of osmo air - dried guava slices which immersed in osmotic solution with calcium chloride was higher than that btained with osmotic solution without the addition of calcium chloride. The results in Tables (1,2 and 4) indicate that the reduction in ascorbic acid percentages of air dried (the control) and osmo air-dried were $50.01 \%$ and from 31.18 to $40.18 \%$ of initial ascorbic acid of the flesh guava. Also, in the same Tables, the results indicate that the quantity of ascorbic acid of osmo- air dried guava slices was higher than that obtained without treated osmosis. These decrements in ascorbic acid content in the conventional air drying (the control) could be due to the oxidation of ascorbic acid during the long periods of drying time. These results are in agreement with Taiwo et al. (2001), Assous(2004) and Zaki (2007).Marfil et al. (2008) showed that osmotic pre-treatment caused a significant reduction in the initial ascorbic acid content of the product, during drying lower degradation rates were observed in osmotically pre-treated whole tomatoes comparing without osmotic pre-treatment. The results in Table (4) indicate that the retention of total phenols of osmo air-dried ranged from 76$82 \%$ of the initial content from phenols ,while the total phenols of air dried guava slices (the control) was decreased to $32 \%$ of initial content. Larrauri et al. (1997) indicated that drying temperature of 100 and $140{ }^{\circ} \mathrm{C}$ caused significant reduction in the total extractable polyphenols (18.6 and 32.6\%), respectively. Also, the same results in Table (4) show that antioxidant activity of osmo air-dried guava slices retained $65-75 \%$ of initial content, while antioxidant activity of air dried was decreased by $48 \%$ of initial content ,these could be due to long drying time. The results in the same Table (4) show that the drying ratio of air dried guava slices was 6.52: 1 . On the other hand, the drying ratio of osmo-air dried guava slices ranged from 2.63: 1 to 2.86: 1 regardless with and without the addition of calcium chloride in osmotic solution. From the results in the same Table (4) one can conclude that osmosis succeeded in reducing drying ratio of guava slices to $40.3-43.8 \%$ of its value in the air dried guava slices.

3.6. Effect of drying on total bacterial and yeast \& mould counts of fresh and osmosed guava slices

The results in Table (5) show that the total bacterial count of dried and osmo air-dried guava slices was 334 and from 112 to $253 \mathrm{cfu} / \mathrm{g}$ regardless with and without the addition of calcium chloride, respectively. In other words, osmo-air drying produced products with lower total microbial count than conventional drying (the control). Also, the same result in Table (5) indicate that the total bacterial count of osmo air-

Table (5): Total bacterial count (x $10 \mathrm{cfu} / \mathrm{g})$ and yeast $\&$ moulds count $(x 10 \mathrm{cfu} / \mathrm{g})$ of guava slices after osmotic dehydration and air drying.

\begin{tabular}{|c|c|c|}
\hline Treatments & Total bacterial count $(x 10 \mathrm{cfu} / \mathrm{g})$ & Yeast \& moulds count $(\times 10 \mathrm{cfu} / \mathrm{g})$ \\
\hline Suc. $\left(T_{1}\right)$ & 14.8 & - \\
\hline Suc.+ Glu. $\left(\mathbf{T}_{2}\right)$ & 20.1 & - \\
\hline Suc.+ Fru.( $\left.\mathbf{T}_{3}\right)$ & 16.7 & - \\
\hline Glu. $\left(\mathbf{T}_{4}\right)$ & 25.3 & - \\
\hline Fru. $\left(\mathbf{T}_{5}\right)$ & 18.5 & - \\
\hline Glu+. Fru. $\left(T_{6}\right)$ & 22.5 & - \\
\hline Suc. $\left(\mathbf{T}_{7}\right)$ & 11.2 & - \\
\hline Suc.+ Glu. $\left(\mathbf{T}_{8}\right)$ & $\mathbf{1 7 . 5}$ & - \\
\hline Suc.+ Fru.(T, $\left.\mathbf{T}_{\mathbf{9}}\right)$ & 13.4 & - \\
\hline Glu. $\left(\mathbf{T}_{10}\right)$ & 21.1 & - \\
\hline Fru.(T $\left.\mathbf{T}_{11}\right)$ & 15.4 & - \\
\hline Glu+. Fru. $\left(T_{12}\right)$ & $\mathbf{1 9 . 5}$ & - \\
\hline control & 33.4 & 1.5 \\
\hline
\end{tabular}


dried guava slices treated with osmosis by osmotic solution adding calcium chloride was lesser than that other treatments .Chardonnet et al. (2001) reported that addition of calcium chloride to the sucrose solution decreased decay caused by all three pathogens, Botrytis cinerea ,Colletotrichum acutatum and Penicillium expansum and the least decay occurred when slices were processed in 15 to $30 \%$ sucrose combined with $2 \%$ calcium chloride. The results in Table (5) show that yeast and moulds of osmo air-dried were absent while, guava dried were 15 cfu/g. Sofos (1995) reported that sorbic acid and its salts are effective antimicrobial agents against many yeasts and molds, as well as bacteria. Also,Chardonnet et al.( 2001) show that high sucrose concentrations have been shown to prevent fungal development and inhibit fermentation by yeasts or molds.

\subsection{Effect of drying on organoleptic properties of fresh and osmosed guava slices}

The results in Table (6) indicate that color, taste, texture ,flavor and overall acceptability scores of the air dried guava slices prepared with osmo-air drying with or without adding calcium chloride were significantly higher than those of dried guava slices prepared with air drying (control treatment). Osmotic pretreatment contributes to retention of flavor in convectively dried fruits, making it more acceptable as ready - to - eat snacks compared to totally air-dried products and an attractive color and did not show any brown pigmentation (Lazarides et al., 1999 and Nono et al.,2002).

The results in the same table show that color scores of osmo air-dried guava slices pretreated with immersion in glucose solution were lower significantly than that prepared with other osmotic solutions. It could be attributed to nonenzymatic browning reactions (Maillard reactions) between amino acids and glucose during drying. Taste scores were not significant of osmo air-dried guava slices; it appears that sugar solutes penetrate into guava slices during osmosis. The results in Table (6) illustrate that texture scores of osmo air-dried treated with sucrose solutions with and without calcium chloride were higher than those of osmo airdried guava slices prepared with other osmotic solution. The results in Table (6) show the overall acceptability scores of osmo air-dried prepared immersion in osmotic solutions, sucrose

Table (6): Mean scores of sensory evaluation ( \pm standard error) of dried and osmo air-dried guava slices.

\begin{tabular}{|c|c|c|c|c|c|}
\hline $\begin{array}{r}\text { Parameters } \\
\text { Treatments }\end{array}$ & Color & Taste & Texture & Flavor & $\begin{array}{c}\text { Overall } \\
\text { acceptability }\end{array}$ \\
\hline Control & $\begin{array}{c}f \\
5.10 \pm 0.65\end{array}$ & $\begin{array}{c}c \\
6.40 \pm 0.65\end{array}$ & $\begin{array}{c}c \\
4.50 \pm 0.35\end{array}$ & $\begin{array}{c}b \\
6.50 \pm 0.50\end{array}$ & $\begin{array}{c}\mathrm{e} \\
5.63 \pm 0.27\end{array}$ \\
\hline Suc. $\left(\mathrm{T}_{1}\right)$ & $\begin{array}{c}\text { bc } \\
7.45 \pm 0.54\end{array}$ & $\begin{array}{c}a b \\
7.70 \pm 0.75\end{array}$ & $\begin{array}{c}a \\
7.30 \pm 0.35\end{array}$ & $\begin{array}{c}a \\
7.30 \pm 0.41\end{array}$ & $\begin{array}{c}a b \\
7.43 \pm 0.41\end{array}$ \\
\hline $\begin{array}{c}\text { Suc.+Glu. }(T \\
\text { S }\end{array}$ & $\begin{array}{c}b c \\
7.30 \pm 0.50\end{array}$ & $\begin{array}{c}\text { ab } \\
8.00 \pm 0.57\end{array}$ & $\begin{array}{c}a \\
7.20 \pm 0.35\end{array}$ & $\begin{array}{c}\mathrm{a} \\
7.45 \pm 0.42\end{array}$ & $\begin{array}{c}\mathrm{ab} \\
7.48 \pm 0.27\end{array}$ \\
\hline $\begin{array}{c}\text { Suc.+ } \\
\text { ru. }\left(\mathbf{T}_{3}\right)\end{array}$ & $\begin{array}{c}\text { bc } \\
7.52 \pm 0.89\end{array}$ & $\begin{array}{c}\text { ab } \\
8.00 \pm 0.50\end{array}$ & $\begin{array}{c}a \\
7.10 \pm 0.45\end{array}$ & $\begin{array}{c}a \\
7.56 \pm 0.22\end{array}$ & $\begin{array}{c}\text { ab } \\
7.54 \pm 0.44\end{array}$ \\
\hline Glu. $\left(\mathbf{T}_{4}\right)$ & $\begin{array}{c}\mathrm{e} \\
6.00 \pm 0.71\end{array}$ & $\begin{array}{c}b \\
7.30 \pm 0.75\end{array}$ & $\begin{array}{c}b \\
5.75 \pm 0.44\end{array}$ & $\begin{array}{c}\mathrm{ab} \\
7.00 \pm 0.49\end{array}$ & $\begin{array}{c}c \\
6.51 \pm 0.35\end{array}$ \\
\hline Fru. $\left(\mathbf{T}_{5}\right)$ & $\begin{array}{c}\text { ab } \\
8.20 \pm 0.44\end{array}$ & $\begin{array}{c}\text { ab } \\
8.10 \pm 0.52\end{array}$ & $\begin{array}{c}b \\
5.65 \pm 0.48\end{array}$ & $\begin{array}{c}a b \\
7.00 \pm 0.48\end{array}$ & $\begin{array}{c}b \\
7.23 \pm 0.35\end{array}$ \\
\hline Glu.+ Fru. $\left(\mathbf{T}_{6}\right)$ & $\begin{array}{c}a b \\
8.00 \pm 0.50\end{array}$ & $\begin{array}{c}\text { ab } \\
7.90 \pm 0.41\end{array}$ & $\begin{array}{c}\text { b } \\
5.80 \pm 0.27\end{array}$ & $\begin{array}{c}a b \\
7.10 \pm 0.41\end{array}$ & $\begin{array}{c}\text { b } \\
7.20 \pm 0.57\end{array}$ \\
\hline Suc. $\left(\mathbf{T}_{7}\right)$ & $\begin{array}{c}\text { ab } \\
8.10 \pm 0.82\end{array}$ & $\begin{array}{c}\text { ab } \\
7.80 \pm 0.27\end{array}$ & $\begin{array}{c}\mathrm{a} \\
7.80 \pm 0.52\end{array}$ & $\begin{array}{c}\mathrm{a} \\
7.50 \pm 0.55\end{array}$ & $\begin{array}{c}\mathrm{a} \\
7.80 \pm 0.56\end{array}$ \\
\hline Suc.+ Glu. $\left(\mathbf{T}_{8}\right)$ & $\begin{array}{c}\text { bc } \\
7.50 \pm 0.53 \\
\end{array}$ & $\begin{array}{c}\text { ab } \\
8.10 \pm 0.67\end{array}$ & $\begin{array}{c}\mathrm{ab} \\
7.40 \pm 0.44\end{array}$ & $\begin{array}{c}a \\
7.52 \pm 0.71 \\
\end{array}$ & $\begin{array}{c}\mathrm{ab} \\
7.63 \pm 0.41\end{array}$ \\
\hline Suc.+ Fru.(T) & $\begin{array}{c}\text { ab } \\
8.32 \pm 0.57\end{array}$ & $\begin{array}{c}\text { ab } \\
8.11 \pm 0.44\end{array}$ & $\begin{array}{c}a \\
7.11 \pm 0.54\end{array}$ & $\begin{array}{c}a \\
7.50 \pm 0.35\end{array}$ & $\begin{array}{c}a \\
7.76 \pm 0.47\end{array}$ \\
\hline Glu. $\left(\mathbf{T}_{10}\right)$ & $\begin{array}{c}\text { de } \\
6.50 \pm 0.35 \\
\end{array}$ & $\begin{array}{c}b \\
7.40 \pm 0.95\end{array}$ & $\begin{array}{c}\text { b } \\
5.80 \pm 0.27\end{array}$ & $\begin{array}{c}a b \\
7.00 \pm 0.54\end{array}$ & $\begin{array}{c}c \\
6.67 \pm 0.35\end{array}$ \\
\hline Fru. $\left(\mathbf{T}_{11}\right)$ & $\begin{array}{c}a \\
8.30 \pm 0.54\end{array}$ & $\begin{array}{c}a \\
8.20 \pm 0.44\end{array}$ & $\begin{array}{c}b \\
5.90 \pm 0.67\end{array}$ & $\begin{array}{c}\text { ab } \\
7.15 \pm 0.47\end{array}$ & $\begin{array}{c}\text { b } \\
7.38 \pm 0.49\end{array}$ \\
\hline Glu+. Fru. $\left(\mathbf{T}_{12}\right)$ & $\begin{array}{c}a b \\
8.00 \pm 0.56\end{array}$ & $\begin{array}{c}\text { ab } \\
8.10 \pm 0.57\end{array}$ & $\begin{array}{c}b \\
5.72 \pm 0.67\end{array}$ & $\begin{array}{c}a b \\
7.13 \pm 0.44\end{array}$ & $\begin{array}{c}\text { b } \\
7.23 \pm 0.27\end{array}$ \\
\hline
\end{tabular}

Means followed by a similar letter with the same column are not significantly different at 0.05 . 
or sucrose: fructose, sucrose: glucose at a ratio 2:1(wt: wt) with adding calcium chloride were highly significant followed the same treatments without adding calcium chloride.

From the aforementioned results, it could be concluded that the osmo air -dried prepared with osmotic solutions, sucrose or sucrose: fructose, sucrose: glucose at a ratio 2:1(wt: wt) with and without addition of calcium chloride during osmossis, respectively then air dried gave not only high quality of sensory evaluation, but also because it's nutritional value. Also, it can substiute sucrose partially by fructose or glucose at a ratio 2:1 (wt: wt), respectively to improve sensory evaluation.

\section{REFERENCES}

Alothman M., Bhat R. and Karim A.A.(2009). Antioxidant capacity and phenolic content of selected tropical fruits from Malaysia, extracted with different solvents. Food Chemistry, 115, 785-788.

A.O.A.C. (2005). Official Methods of Analysis of AOAC. International 18th Edition, Published by AOAC International. Maryland 208772417. USA.

A.P.H.A. (1992). Standard methods for the examination of dairy product. American public Health Association. Inc. 16th Ed., Washington, D.C.

Assous M.T.M.(2004). Effect of ultrasound during osmotic dehydration on the quality of dehydrated tropical fruits. Ph.D. Thesis, Food Sci. and Technol. Dept., Fac. of Agric., Cairo Univ., Egypt.

Bashir H.I. and Abu-Goukh A.A. (2003). Compositional changes during guava fruit ripening. Food Chemistry, 80, 557-563.

Bolin H. R., Huxsol C.C., Jackson R. and NG K.C. (1983).Effect of osmotic agents and concentration on fruit quality. J. Food Sci. 48: $202-205$.

Carabasa-Giribet M. and Ibarz-Ribas A. (2000). Kinetics of color development in aqueous glucose systems at high temperature .J. Food Eng.,44,181-189.

Chardonnet C.O., Sams EC.E., Conway W.S., Mount J.R. and Draughon F.A. (2001). Osmotic dehydration of apple slices using a sucrose $/ \mathrm{cacl}_{2}$ combination to control spoilage by Botrytis cinerea, Colletotrichum acutatum, and Penicillium xpansum. J. of Food Protection, Vol., 64, No.9, 1425-429.

Correa J.L.G., Pereira L.M., Vieiral G.S. and Hubinger M. D. (2010). Mass transfer kinetics of pulsed vacuum osmotic dehydration of guava. Journal of Food Engineering, 96, 498- 504.

Di Scala K. and Crapiste G. (2008). Drying kinetics and quality changes during drying of red pepper. LWT - Food Sci. Technol. 41 (5), $789-795$.

Egyptian Standard (2007). Egyptian Organization for standardization. Fruit Dried Fig. Es: 2801.

El Bulk R. E., Babiker E. E. and El Tinay A. H. (1997). Changes in chemical composition of guava fruits during development and ripening. Food Chemistry, Vol. 59, No. 3, pp. 395-399.

El-Gharably A. M., Nagip A. I. and Rizk E.M. (2009). Evaluation of quality attribuites for Egyptian apricot and fig produced by osmo drying process .Annals Agric. Sci., Ain Shams Uni.,Cairo,54(2),359- 371.

Gutierrez R.M.P., Mitchell S. and Solis R.V. (2008). Psidium guajava: A review of its traditional uses, phytochemistry and pharmacology. Journal of Ethnopharmacology 117,1-27.

Jaiswal U. and Jaiswal V.S. (2005). Psidium guajava. In: Litz, R.E. (Ed.), Biotechnology of fruit and nut crops. CAB International, Wallingford, UK, pp. 394-401.

Khalil K.E.(1997).Optimization of processing parameters and storage stability of mango and guava leathers .Menofiya J.Agric. Res., Vol. 22,No.3,831-856.

Larrauri J.A., Rupérez P. and Saura-Calixto F.(1997). Effect of drying temperature on the stability of polyphenols and antioxidant activity of red rape pomace peels. J. Agric. Food Chem., 45 (4),1390-1393.

Lazarides H.N., Fito P., Chiralt A., Gekas V. and Lenart A. (1999). Advances in osmotic dehydration. In: Processing foods. F.A.R. Oliveira, J.C., Oliveira, M.E. Hendrickx, D. Korr and L.G.M. Gorris. (eds.) CRC Press, London, pp.175 - 195.

Marfil P.H.M, Santos E.M. and Telis V.R.N.(2008). Ascorbic acid degradation kinetics in tomatoes at different drying conditions. LWT - Food Science and Technology, 41, 1642-1647.

Mercado-Silva E., Benito-Bautista P. and Garc1'a - Velasco M. ( 1998 ). Fruit development, harvest index and ripening changes of guavas produced in central Mexico. Postharvest Biology and Technology, $13,143-150$.

Monsalve-Gonzalez A., Barbosa-Canovas G.V. and Cavalieri R.P. (1993). Mass transfer and 
textural changes during processing of apples by combined methods. J. Food Sci. 58 (5) : $1118-1124$.

Mujica-Paz H., Valez-Fragoso A.,Lopez-Malo A., Palou E. and Welti- Chanes J.(2003). Impregnation and osmotic dehydration of some fruits: effect of the vacuum pressure and syrup concentration. J.of Food Engineering, 57,305-314.

Nono Y.J., Reynes M., Zakhia N., Raoult-Wack A.L. and Giroux F. (2002). Mise au point d'un procédé combiné de déshydratation imprégnation par immersion et séchage de bananes (Musa acuminata groupe Cavendish).

J. Food Eng. 55: $231-236$.

Omar M.I.A,El-Waseif K.H.M. and El-Fiky M.S.H. (2007). Evaluation of fruits of some guava varieties intended for processing. Egyptian J. of Nutrition Vol. XXII, No. 2,141-160.

Osorio C., Forero D.P. and Carriazo G .J. (2011). Characterisation and performance assessment of guava (Psidium guajava L.) Microencapsulates obtained by spray-drying. Food Research International 44, 1174-1181.

Panades G., Fito P., Aguiar G., Nunez de Villavicencio M. and Acosta V.(2006). Osmotic dehydration of guava: Influence of operating parameters on process kinetics. Journal of Food Engineering, 72, 383-389.

Park K.J., Bin A. and Brod F.B.R. (2002). Drying of pear d'Anjou with and without osmotic dehydration . Journal of Food Engineering 56 ,97-103.

Ponting J.D., Waters G.G., Forrey R.R., Jackson R. and Stanley W.L. (1966).Osmotic dehydration of fruits.Food Technol. $10: 125-128$.

Prothon F., Ahrne L.M., Funebo T., Kidman S., Langton M. and Sjöholm I. (2001). Effects of combined osmotic and microwave dehydration of apple on texture, microstructure and rehydration characteristics. Lebensmittel Wissenschaft und Technologie $34: 95-101$.

Qi H., LeMaguer M., and Sharma S. K. (1998). Design and selection of processing conditions of a pilot scale contactor for continuous osmotic dehydration of carrots. Journal of Food Process Engineering, 21, 75-88.

Rai M. K., Jaiswal V.S. and Jaiswal U. (2008). Encapsulation of shoot tips of guava (Psidium guajava $\mathrm{L}$.) for short-term storage and germplasm exchange. Scientia Horticulturae, $118,33-38$.
Ranganna S. (1977).Manual of analysis of fruit and vegetable products. Tata McGraw-Hill Publishing Company Limited, NewDelhi.

Singh S. P. and Pal R. K. (2008). Controlled atmosphere storage of guava (Psidium guajava L.) fruit. Postharvest Biology and Technology, 47, 296-306.

Soares S.D., Pereira P., Marques M.M. and Monteiro A.R. (2007). Volatile and nonvolatile chemical composition of the white guava fruit (Psidium guajava) at different stages of maturity. Food Chemistry 100, 1521.

Sofos J.N. (1995).Antimicrobial agents. In: Food additive toxicology. J. A. Maga, Anthony, T.Tu. (ed.).Marcel Dekker, Inc., New York, Basel, Hong Kong.

SPSS (1990). SPSS /PC for the IBM PC/XI. Chicago IL. USA.

Swain T. and Hillis W.E. (1959). The phenolic constituents of Prunus domestica. 1- The quantitative analysis of phenolic constituents. J. Sci. Food Agric. 10: 63- 68.

Taiwo K. A., Angersbach A., Beatrice I. AdeOmowaye O. and Knorr D. (2001). Effect of pretreatments on the diffusion kinetics and some quality parameters of osmotically dehydrated apple slices. J. Agric. Food Chem., 49, 2804-2811.

Tedjo W. ,Taiwo K.A. ,Eshtiaghi M.N. and Knorr D.(2002). Comparison of pretreatment methods on water and solid diffusion kinetics of osmotically dehydrated mangos. Journal of Food Engineering ,53, 133-142.

Thaipong K., Boonprakob U., Crosby K., Cisneros-Zevallos L. and Byrne D.H. (2006). Comparison of ABTS, DPPH, FRAP, and ORAC assays for estimating antioxidant activity from guava fruit extracts. Journal of Food Composition and Analysis 19, 669-675.

Van Arsdel W.B. and Copley M.J. (1964). Food Dehydration. AVI Publishing Co. Inc., Westport, Connecticut.

Yan L.Y., Teng L. T. and Jhi T.J.(2006). Antioxidant properties of guava fruit: omparison with some local fruits. Sunway Academic J.,3,3-9.

Zaki Sahar M. (2007). Effect of osmotic and conventional dehydration on quality of some fruits and vegetables .J. Agric. Sci. Manoura Uni., 32 (2) : 1179 -1201. 


\section{تأثير التجفيف الاسموزى والتجفيف بالهواءعلى جودة شرائح الجوافة \\ مصطفى طله محمدى عسوس - قدرى حامد محم الوصيف - سحر محمد ذكى \\ معهد بحوث تكنولوجيا الأغذية ـ مركز البحوث الزراعية - الجيزة - مصر}

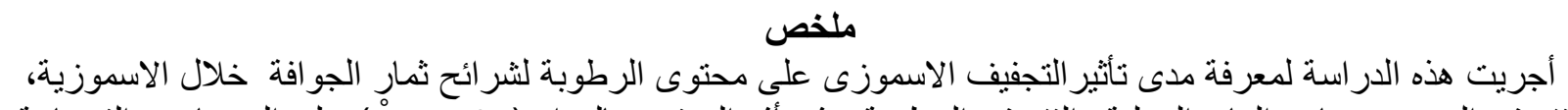

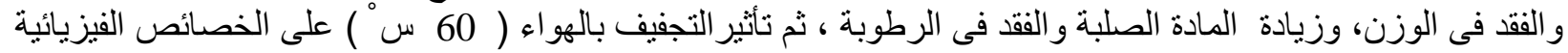

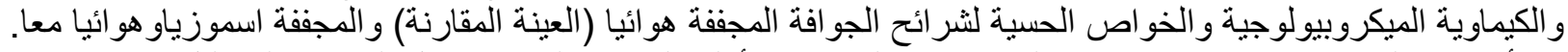

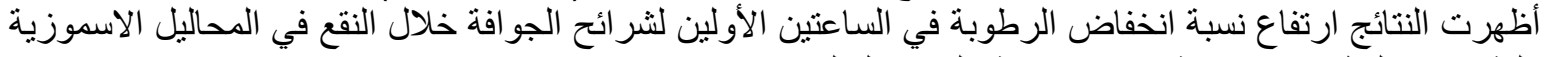

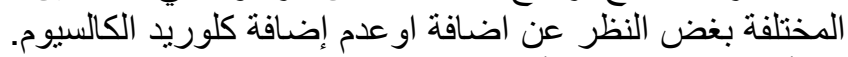

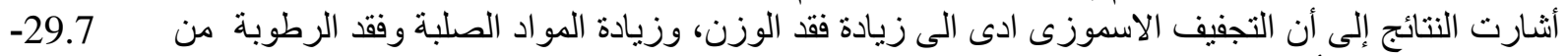

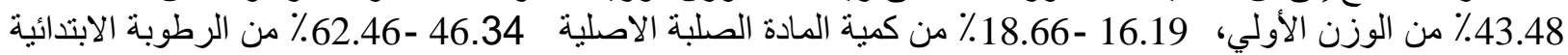

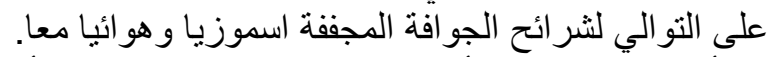

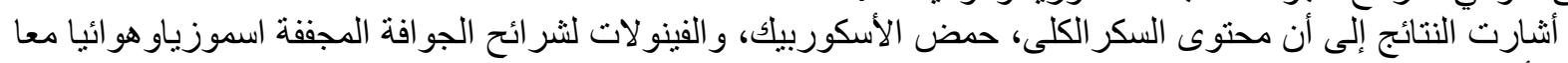

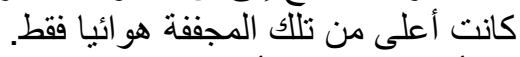

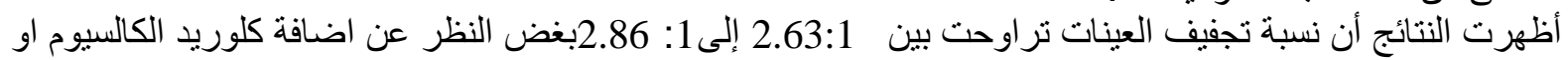

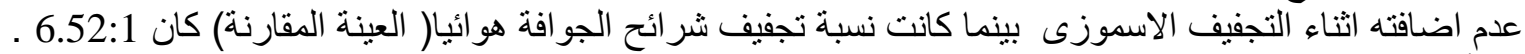

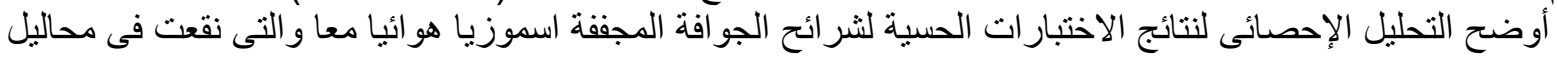

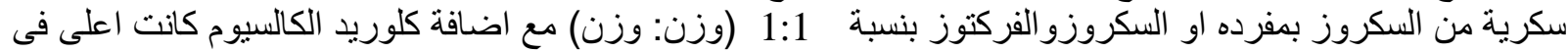

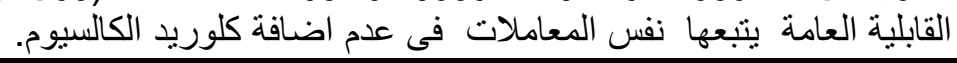

المجلة العلمية لكلية الزراعة - جامعة القاهرة - المجلد (63) العدد الثالث (يوليو 2012): 275-285. 